\title{
Chorus and Agon in the Political Novel: Staging Left-Wing Arguments in H.G. Wells, Iris Murdoch and Doris Lessing
}

Politicised literary criticism of the last three or four decades-especially that which takes its bearings from the Marxist tradition—has often assumed that the "political unconscious" is where a text's politics lie, rather than in any political arguments that are articulated in the diegetic world of the text, or by the narrator. Under the influence of Theodor Adorno and Fredric Jameson, critics have tended to see overtly political fiction (especially committed literature) as naïvely referential: a novel's politics, under this paradigm, need to be deduced from it silences or omissions, or drawn out from form itself. As Isobel Armstrong argued in Novel Politics (2016), "[t]o attempt to discover a democratic aesthetic in the explicitly 'political' novel is to look in the wrong place ... the modern category of 'social problem' too often preordains a limited thematic reading" (7). Sianne Ngai, meanwhile, pinpoints some of the formal attributes of the novel of ideas (of which the political novel is a subcategory) as gimmicks that are particularly problematic for scholars of the novel: "Allegory, direct speech by narrators, and direct speech by characters: these ancient didactic devices ... distance the novel from its métier-narration-and systematically push its form closer to those of the essay, lecture, or play" (118). I am both more sympathetic to the political novel of ideas than Ngai or Armstrong, and more hopeful that tools can be found to go beyond the kind of "limited thematic reading" (Armstrong) that befits what Ngai calls a "self-interpreting artwork" (126). Left-wing ideas (and often explicitly Marxist ones) are often articulated in novels, and politicised criticism has been surprisingly reluctant to reflect on how this functions. 
Recent work by Amanda Anderson, Benjamin Kohlmann and others has begun to furnish us with a critical vocabulary better fitted to dealing with the explicit, manifest political arguments one finds in novels, and to contend with politically committed writers who write about politically committed characters. This work could be thought of in relation to the shift, influentially described by Stephen Best and Sharon Marcus, away from Jamesonian symptomatic reading towards a form of "surface reading". However, if the critics of surface reading tend to characterise it as "undeniably depoliticized, even anti-political” (Penteado 96), Anderson, Kohlmann, and others who work in this way could hardly be accused of this. As she describes it in Bleak Liberalism (2016) Anderson's work “seeks to establish the centrality and significance of argument as a formal mode in the political novel (typically enacted through political or ideological discussions between characters) as well as political novelists' common interest in depicting a lived relation to political commitment or belief" (79). Anderson's work has enabled us better to understand the formal organisation of political discourse and debate within novels, and in relation to plot, character, style and various formal devices. Her brilliant and pathbreaking book focusses on novels of political deliberation that engage with the political philosophy of liberalism, which has, in turn been too easily dismissed (by the academic left) as "a governing and normalizing ideology for the consolidation of a capitalist or disciplinary status quo" (2018 12). The fundamental insights of Bleak Liberalism need not lead us to conclude, however, that liberalism and the novel are inevitably intertwined. Distortions may arise if the idea of (bleak) liberalism is extended to cover all novelistic representations of political argument. Anderson herself is judicious in her application of the term. However, if bleak liberalism is seen as paradigmatic of the workings of political novels in general, it will to narrow the bandwidth in terms of the 
kinds of argument and attitude that the political novel can be thought to encompass. Is political debate inherently liberal? If so, Anderson's term might lead us back, rather unexpectedly, to the conclusion that the truly radical artworks must by definition refuse to participate in the formal conventions of the discursive political novel. The risk of using bleak liberalism as a general heuristic for understanding novelistic depictions of political debate is that it suggests these exist in what Chantal Mouffe calls a "consensus at the centre". For Mouffe, such a consensus "deprives democratic citizens of an agonistic debate where they can make their voices heard and choose between real alternatives" (2013 119). Rather than seeing the political, as liberal theorists like Hannah Arendt did, as a "space of freedom and deliberation," Mouffe sees it as "a space of power, conflict and antagonism” (2005 9). Mouffe's thought thus offers an opportunity for us to theorise a kind of political novel that is less liberal and deliberative than Anderson's examples, and one in which counterhegemonic, left-wing arguments are articulated in a political space that is characterised by the workings of "power, conflict and antagonism."

This essay explores three political novels that stretch and test the limits of the (bleak) liberal tradition-H.G. Wells's Kipps (1905), Iris Murdoch's Under the Net (1954), and Doris Lessing's A Proper Marriage (1954)—making the argument that agonism, in the sense theorised by Mouffe, is central to the way left-wing arguments, often explicitly Marxist ones, enter the novelistic scene. Compared with Anderson's Bleak Liberalism, Benjamin Kohlmann's important study of 1930s committed literature, Committed Styles (2014) shows a slightly different way of taking the political novel seriously_not as an implicitly liberal form that brings opposing views into dialogue and seeks common ground through debate, but one that can capture the extreme polarisation of agonistic conflict. "[T]hirties politicized writing," Kohlmann 
writes, "needs to be understood in relation to an Old Left politics which emphasizes the inevitability of social conflict and the extreme urgency of 'taking sides'” (13). Critical accounts of 1930 s literature have frequently sought to contain its radical and polarising energies by casting it as a literary-historical anomaly, a "low, dishonest decade" when writerly commitment led to aesthetic failure. Referring (like Kohlmann) to Nancy Cunard's pamphlet, Authors Take Sides on the Spanish Civil War (1937), Peter Kalliney points out in the introduction to this special issue that a literature in which fictional characters and writers "take sides" speaks with particular resonance to the political investments of today's students. The polemical framing of a "long 1930s" (Kohlmann and Taunton) tends to imply that intransigent, polarising political writing is a normal feature of the literary field, not only in 1930s England, but also across the twentieth century and into the present, as well as around the world. Jeanne-Marie Jackson has recently theorised certain Zimbabwean novels (written during the years of the Mugabe regime) as "agonistic in form, subjecting even plurality itself to contestation and debate" (340). Drawing on Bonnie Honig's work on agonism, Jackson describes "a tradition that privileges categorical conflict over categorical dissolution, thereby relativizing plurality to maintain sharper structures of disagreement" (342). Where critics have often found in the supposed dialogism of the novel form a template for "plurality" and liberalism (however bleak), Jackson advocates instead "digging deeper to grapple with locally and narratively emplaced structures of debate" (358).

With this in mind, Chantal Mouffe's theorisation of politics as inherently agonistic provides a promising frame in which to understand those political novels which do not easily fit the model of liberal deliberation, but are also disqualified from any Adornian or Jamesonian reading by making their political arguments too explicit. To 
begin with, Mouffe rejects entirely the idea that the aim of politics should be to strive for "a society beyond division and power" (2013 83). "There will always be antagonisms, struggles, and partial opaqueness of the social," she writes. "This is why the myth of communism as a transparent and reconciled society—clearly implying the end of politics—had to be abandoned" (2019 3). A post-conflict, communist society is the implicit goal of the Adornian tradition of literary criticism that has valued difficult texts that radically reject the representational norms and the institutional conditions of the literary marketplace. The utopian impulse of modern art as Adorno described it was to assert a kind of (always partial) autonomy, from the marketplace and the various fora of democratic debate (popular culture, parliamentary politics, the political novel). Rather than a flight from these institutions, Mouffe's work encourages engagement in and with them.

Mouffe's insistence that politics is by nature conflictual constitutes a demand for more leeway from the liberal centre (to allow counter-hegemonic arguments to be heard) but it also demands of the left some accommodation with the hegemonic institutions of capitalist society:

While consensus is no doubt necessary, it must be accompanied by dissent. Consensus is needed on the institutions of that are constitutive of liberal democracy and on the ethico-political values that should inform political association. But there will always be disagreement concerning the meaning of those values and the way they should be implemented. This consensus will therefore always be a 'conflictual consensus'. (2013 8) 
The function of democratic institutions, in this model, is to provide sites of "conflictual consensus", which recognise and legitimate conflict, and provide a forum in which it can take an agonistic form. The political novel is one such institution, I claim. Critics like Adorno and Armstrong encourage us to walk away from the political, committed novel, as an inherently fallen form, too embedded in the world as it finds it. This paper hopes to lend encouragement (and acclaim) to critics who would engage in the hurly burly of democratic debate as they find it in novels, rather than piously rise above it.

With this in mind, I turn to three very different but self-consciously political texts in which left-wing arguments are articulated by characters and given weight: I want to ask what is at stake when writers put left-wing arguments into the mouths of their characters and situate these in relation to other arguments, and within the fictional lifeworlds of the novels themselves. My suggestion is that the kind of debate and disagreement one finds in them goes beyond the liberal discussion novel, at least at times. In dramatising left-wing speech, they articulate (in Mouffe's terms) "the struggle between opposing hegemonic projects which can never be reconciled rationally, one of them needing to be defeated" (2013 9). I use the term "dramatise" advisedly. Ngai is surely right to point to the constant potential (or danger as she sees it) for the novel to overlap with "the essay, lecture, or play". I would only suggest that this hybridity is constitutive of the novel form, rather than an aberration from it, and certainly an aspect of the political novel that ought not to be ignored. We need to attend carefully to this formal hybridity to understand the political novel as a form. With that in mind, the argument I set out below is not a call for attention to unmediated political content: on the contrary, what I want to insist on is that the mediation of political ideas in novels is crucially important. It would be a waste of 
time to deny that the political arguments in question are both contained in novels and have a reality independent of those novels. The political novel is one genre that could look a lot different if critics were to "realize that literary forms always come embedded in world-building language that conveys specific meanings, themes and subject matter" and that "texts are never just forms but also expressions, actions, and interventions" (Moi, 67). What follows is not an attempt to discard formal analysis, but to describe and analyse the formal properties of some discursive political novels.

In her brilliant but neglected book Ideas and the Novel (1981), Mary McCarthy notes that "if you are going to voice ideas in a novel, plainly you will need a spokesman," although twentieth-century novelists "learned to become embarrassed about the device" (30-32). The term "chorus character" has the benefit of gender neutrality, and I prefer it to "spokesman" here because it resonates usefully with the chorus as it appears in Greek drama. Indeed, both of the key terms of my title, chorus and agon, derive from the Greek stage, and they constitute an immediate acknowledgement of the dramatic qualities of political novels that are often driven by character-character dialogue, and which do—as Ngai suggests—deploy "ancient didactic devices", albeit in new ways. The chorus is a feature of the Greek drama that persists in English literature mainly in sublimated forms: the weird sisters in Macbeth, Lear's fool, and, in the modern political novel, the chorus character. ${ }^{\text {i While }}$ "spokesman" implies a direct line to the author's opinions, the function of the chorus is more contested. Aristotle saw it as representative of the moral intelligence of "the people", while Schlegel thought that it embodied on the stage an ideal audience. Nietzsche dismissed these conventional accounts in The Birth of Tragedy, arguing instead that the chorus was a Dionysiac religious ritual that had been brought onto 
the stage (35-40). Even among the three tragedies that make up the Oresteia, Aeschylus constitutes the chorus of different social groups (the old men of Argos in Agamemnon; women slaves from the palace in Libation Bearers; and the furies themselves in Eumenides), which perform highly distinctive roles. In some Greek dramas the chorus seems to act as some kind of centre of moral authority or popular will, but in others this position is far from settled. In Lysistrata, there is a split chorus which pits men against women. The chorus character is a common but often unremarked figure in the political novel, stepping into the diegesis to articulate arguments and ideas which are sometimes close to the author's own, but also sometimes exceed or undermine this "spokesman" function. One of the reasons novelists, and perhaps to an even greater extent critics, have become embarrassed about this device is because the very idea of the chorus character underlines certain didactic tendencies of the novel form. A chorus on the Greek stage involved multiple people saying (or singing) the same words at once-an instance of collective utterance. While the chorus character in the political novel is generally a unitary figure, such a character generally shares this tendency for monologism, acting as a collective (and potentially collectivist) voice that articulates an "opposing hegemonic project”.

In the agonistic political novels that I describe below, the function of the novel (to use Mouffe's terms again) is not to "negotiate a compromise among competing interests" (2013 9), as we might expect from novels in the liberal tradition. When chorus characters engage in character-character dialogue, they are not good conversationalists in the terms Richard Sennett set out in Together: The Rituals, Pleasures and Politics of Cooperation (2012). Sennett describes two forms of productive verbal exchange: the "dialectical conversation" where, through the "verbal 
play of opposites", the parties will "come eventually to a common understanding"; and the "dialogical conversation" in which "discussion which does not resolve itself by finding common ground", although "through the process of exchange people may become more aware of their own views and their understanding of one another" (1819). Chorus characters tend to do something that Sennett argues is fatal to either dialectical or dialogical conversations, by focusing merely on clarifying their own positions. They could be said to suffer, in fact, from the "fetish of assertion" (Sennett borrows the term from Bernard Williams): an "impulse to ram home your case as though its content is all that counts" (18), poisonous to the possibility of constructive (liberal) dialogue.

I focus here on three chorus characters who enter the novelistic scene to set out an explicitly left-wing explanation of the problems that beset the central protagonist. These characters are Masterman in Wells's Kipps, Lefty in Murdoch's Under the Net, and Anton in Lessing's Children of Violence sequence. The contents of these characters' arguments, the formal properties of the novels in which they appear, and the political predilections of their authors differ profoundly. Yet these novels share in common an essentially agonistic structure, with a chorus character and a prominent role for character-character dialogue. The chorus characters' arguments are rarely if ever presented without some form of contestation, and often in stichomythic dialogue with the novel's main protagonist, or other character(s) (as is frequently the case with choruses in Greek drama). It is not unusual for a novel to include something that feels like an essay or a lecture delivered by a chorus character, but novels do something that lectures and essays do not by including argumentative responses, and demanding that readers reflect on the effects of an argument in a fictional world. Such novels test political argument against specific diegetic conditions, and force us 
to reflect on the roles of rhetoric, comedy, irony, characterisation, motivation, the relation between a character's left-wing discourse and the narration, and the relation between politicised character-character dialogue and plot. The effects of didactic speech are often mitigated in political novels by a sense of irresolution, where the chorus character's intervention has unpredictable or limited effects on the protagonist, or gets derailed by other factors in the plot—romantic, personal, or otherwise caught up in the embodied, creatural nature of the political novel's lifeworld. Equipped with these tools for thinking about left-wing speech in the novel, about agonism, and about the chorus character, I now turn to my first example, H.G. Wells's Kipps.

\section{Kipps}

In Kipps: The Story of a Simple Soul (1905), Wells explores the Edwardian class system by making his draper's assistant protagonist unexpectedly inherit a fortune worth twelve hundred pounds a year. Artie Kipps seeks to acquire the manners and mores of the class in which his money seems to put him, but he painfully and comically fails and becomes a laughing stock. He comes into contact with socialist arguments via his old acquaintance Sid and-even more so-Sid's friend Masterman. Partly under the influence of these arguments, and partly because of his recurrent social humiliations, Kipps rejects the society gatherings where he had been trying to make his name, and marries Sid's sister Ann. They settle down to a comfortable existence free from the pressure to adapt to the social norms that attach 
to their newfound wealth, and from the intellectual and political challenge of socialism.

Through Masterman, Wells introduced into the diegetic world of Kipps political arguments with which he was sympathetic. ${ }^{\text {ii }}$ Yet once this has been acknowledged it raises a series of further questions about the manner in which these arguments are presented. For example, it will be important to consider what Mastermind says, how the narrator reports his speech, how the other characters react to it, and how his discourse is seen to influence the narrative, or not. Masterman first enters the novel about half way through, where he makes a set piece tirade whose Shakespearian refrain is that "the times are out of joint" (306). He starts with Kipps's personal situation, arguing that money cannot provide happiness, and then becomes "angry" (310), broadening into more wide-ranging diatribe to claim that "the rich to-day have neither heart nor imagination" (311). Masterman's rhetoric resonates with the kind of political arguments Wells was making around this time in his political writing such as his celebrated tract, This Misery of Boots (1905, revised 1907). What does it mean when political novelists put arguments they might have made themselves into the mouths of fictional characters?

For one thing, inserting socialist arguments into the novel enables Wells to investigate the effects of this discourse in his fictional universe. Strikingly, the themes and rhetoric of Masterman's speech bleed into Kipps's thoughts as they are conveyed in free indirect discourse. For example, in one comical scene, Kipps is dining alone at the Royal Grand Hotel, and suffers the pangs of humiliation as he fails to use his cutlery correctly and ends up with vol au vent down his shirt: 
Mutton came with peas. He arrested the hand of the waiter. "No peas," he said. He knew something of the difficulty and danger of eating peas. Then, when the peas went away again he was embittered again. ... Echoes of Masterman's burning rhetoric began to reverberate in his mind. Nice lot of people these were to laugh at anyone! Women half undressed! (323-4, Wells's ellipsis)

Wells's use of free indirect discourse shows how Kipps both absorbs Masterman's arguments and deploys them imperfectly, in a way that comically absolves him of his failure to adapt to his new class position, enabling him instead to transfer the blame onto a beast called capitalism. The socialist argument is mobilised here not so much to leverage the protagonist into political activism, but to provide him with a consoling psychological compensation for social failure.

At certain points, the things Masterman says and the way the narrator presents them conspire to undermine the arguments he makes. Some of this may have to do with the attitudes of the twenty-first-century reader, who is likely to be deeply alienated by Masterman's claim that “[t]here isn't a woman among the swim of society at the present time, who wouldn't sell herself, body and soul, who wouldn't lick the boots of a Jew or marry a nigger, rather than live decently on a hundred a year!" (312). How close this was to Wells's unconscious attitudes is a moot point, though the fact that Wells explicitly disavowed racism makes it possible that Wells turned up the volume on this sexist and racist rant to hint at weaknesses in Masterman's character, and perhaps his arguments. ${ }^{\text {iii }}$ Certainly it is interesting that after this particular outburst the consumptive Masterman "fell into a struggle with his cough and spat a gout of blood" (312). Wells also nudges the reader to think of Masterman as a rather vain figure: "His voice rose with impotent anger. 'I'm a better 
man than any ten princes alive! ... I've thrown my life away to make myself too good for this huckster's scramble."' (pp.313-4). Kipps, on the other hand, is a weak and uncertain interlocutor and his conversation with Masterman is a one-way affair. Masterman is less a socratic teacher than the owner of a pre-scripted monologue against capitalist society, and Wells's treatment of these political arguments focusses not so much on putting them into dialogue with Kipps's limited verbal responses, instead exploring their effects on the untutored mind.

All this hints at one of the key considerations for novelists who would put their own arguments into the mouths of characters: identification. In a recent essay, "Identifying with Characters", Rita Felski asks us to "question the frequent conflation of identification with empathy"-not to deny that empathy is one important form of identification, but to insist that identification takes other forms too, some of which she elaborates on. Felski's detractors often focus on the apparently depoliticising tendencies of postcritique, but her recent work has also made it possible to think in new ways about politicised writing, especially about explicit political commitments in texts. Of most relevance to the present discussion is Felski's discussion of "allegiance", a form of identification that "is in play when we find ourselves siding with a character and what we take that character to stand for". It "speaks to the question of how ethical or political values - that is, acts of evaluating-draw audiences closer to some figures rather than others" (95-6). As the examples above imply, the scope and direction of readerly identification is not completely (perhaps not even mostly) within the novelist's control. Views compatible with certain strands of Edwardian socialism may later come to seem poisonously racist and sexist. Does Masterman's consumptive cough make readers empathise with him, or does it make him seem weak and motivated by resentment? It is hard to think that all of the things that make 
empathetic identification with Masterman difficult are accidents. Readerly sympathies flow inexorably to Kipps, the "simple soul" of the novel's subtitle even if some of Masterman's arguments might attract "allegiance".

Kipps encourages a bifurcation of identification, as empathy for Kipps and allegiance with the socialist arguments he eventually rejects pull the reader in different directions. Effects like this are rarely commented on by critics, but quite common in the political novel-indeed they may be archetypal of a distinctively twentieth-century tradition of the political novel. Stephen Spender reflected on a similar question in World Within World (1951), recounting a conversation he had with his more committed Communist friend Edward Upward (referred to as "Chalmers" in Spender's autobiographical writing):

The idea for the novel which Chalmers had once sketched when we walked through Berlin, near the Gedaechtniskirche-a novel in which the virtuous and sympathetic characters would be capitalists and the unpleasant ones Communists, but which would show that nevertheless the Communists were "right" because they were "on the side of history"-seemed now a parable of our time: a parable, though, whose moral I took in the sense opposite to that intended by Chalmers. I began to realise what I had always known in my heart: that there is no "historic correctness" which achieves good independently and in spite of the moral qualities of those who support the cause. (252)

Here Cold War politics are mapped onto a discussion of approaches to the novel in a way that bypasses the well-worn opposition between socialist realism and bourgeois modernism. Spender insists that the distinction that Felski would later make between 
identification by empathy and by allegiance is, or ought to be, a false one. The novel that Upward wanted to write would simply end up inadvertently proving the Marxist analysis wrong - for any well-adjusted reader the characters who command empathy because of their "moral qualities" would automatically compel assent for their political arguments.

The divergence in Kipps between the didactic political message delivered by Masterman and the sympathetic life choices of Artie Kipps is emphasised by the sentimental ending of the novel. This involves a deliberate setting aside of Masterman's arguments by Kipps and Ann.

"We'll jest 'ave a sensible little 'ouse, and sensible things. No art or anything of that sort, nothing stuck-up or anything, but jest sensible. We'll be as right as anything, Ann."

"No socialism," said Ann, starting a lurking doubt.

"No socialism," said Kipps; "just sensible, that's all."

"I dessay it's all right for them that understand it, Artie, but I don't agree with this socialism."

"I don't neither, reely," said Kipps. "I can't argue about it, but it don't seem real like to me. All the same Masterman's a clever fellow, Ann."

"I didn't like 'im at first, Artie, but I do now_-in a way. You don't understand 'im all at once."

"'E's so clever," said Kipps. "Arf the time I can't make out what 'e's up to. 'E's the cleverest chap I ever met. I never 'eard such talking. 'E ought to write a book.... It's a rum world, Ann, when a chap like that isn't 'ardly able to earn a living." (366-7) 
This passage exemplifies the complexity with which didactic left-wing speech is often met in the political novel. Ultimately Masterman's arguments fall foul of the marriage plot as well as a certain implied authorial sympathy for the anti-intellectual domestic culture of the lower-middle-class "simple soul". Masterman's fiery condemnations cannot be assimilated into a "consensus at the centre," and remain as part of an antagonistic, counter-hegemonic project that is fully articulated in the novel and yet cannot be reconciled with Kipps's chosen way of life or his ideological preconceptions.

An invaluable essay by Harris Wilson analyses (and helpfully reproduces) an alternative ending to Kipps from an earlier draft of Wells's novel, in which Masterman makes an additional final appearance, only to die of the consumptive cough that persistently interrupts his monologues. "Wells, in this episode, slips into the discursive and didactic," Wilson notes, "his characters are almost forgotten as they expound his own social ideas and criticism." Eventually Wells cut the scene, Wilson concludes, because his "artistic sense overcame his urge to propagandize" (69). For me, Wilson's conclusion gives us a too-easy (and by now all too familiar) opposition between "artistic sense" and the "urge to propagandize". Taking the political novel seriously and on its own terms involves deconstructing that binary, and allowing for Wells's didactic political intentions to become part of his artistic achievement, rather than existing in opposition to it. The way in which Wells changed the ending did not remove the political arguments from Kipps-they remain present but embedded in an agonistic structure that situates their didactic function in relation, not so much to counter-arguments, but to the rich complexity of the Edwardian class system and the educational limitations under which Kipps labours. 


\section{Under the Net}

Iris Murdoch's first novel, Under the Net, positions left-wing political discourse within a more wide-ranging set of philosophical debates that reflect on the nature of dialogue itself. As in Kipps, the character who carries the left-wing arguments, Lefty, does not appear until the second half of the novel. In this case the events and discussions that precede the introduction of Lefty significantly inform the ways that left-wing arguments are instrumentalised in the subsequent text. The narratorprotagonist Jake Donaghue is a translator who has fallen on hard times, and begins the novel having been kicked out by his girlfriend and in search of somewhere to live. He then becomes involved in a series of conversations whose topics vary from the everyday to the deeply personal to the political and the philosophical. His most significant interlocutor is not Lefty but Hugo Bellfounder, whom he had first encountered several years before the action of the novel, when they were both guinea pigs in a cold-cure clinic. What Jake gains from Hugo is not an all-embracing philosophical theory of reality so much as an approach to dialogue and philosophical questioning. Murdoch's debt to Wittgenstein is evident here: the novel's title alludes to his Tractatus (Conradi 32). Jake notes in his narration: "I have never met a man more destitute than Hugo of anything which can be called a metaphysic or general Weltanschauung. It was rather perhaps that of each thing he met he wanted to know the nature-and he seemed to approach this question in each instance with an absolute freshness of mind" (Murdoch 68). Jake is captivated by Hugo's arguments, questions, and conversational style: 
Of each thing [Hugo] wanted to know the nature-and he seemed to approach this question in each instance with an absolute freshness of mind. The results were often astonishing. I remember a conversation which we once had about translating. Hugo knew nothing about translating, but when he learnt that I was a translator he wanted to know what it was like. I remember him going on and on, asking questions such as: what do you mean when you say that you think the meaning in French? How do you know you're thinking it in French? If you see a picture in your mind how do you know it's a French picture? Or is it that you say the French word to yourself? [...] what seemed to me to be the simplest utterance soon became, under the repeated pressure of his "You mean", a dark and confused saying of which I no longer myself knew the meaning. (68)

This richly dialogic approach to conversation is held up by Jake as an ideal, and the left-wing arguments that he subsequently encounters are to some extent framed by it.

Over the course of Under the Net, various forms of monologism arise to pose a challenge to Jake's celebration of Hugo's discursive style. The first comes when, without Hugo's knowledge, Jake begins to make notes of their conversations and gradually starts to form these into a manuscript dialogue. After circulating the manuscripts among various acquaintances, who are enthusiastic, Jake is approached by a publisher, and - apparently without Hugo's knowledge-the book is published as The Silencer. Looking back on the whole episode, Jake suggests a paradox at the heart of his published text: 
I kept it in the form of a dialogue between two characters called Tamarus and Annandine. The curious thing was that I could see quite clearly that this work was from start to finish an objective justification of Hugo's attitude. That is, it was a travesty and falsification of our conversations. Compared with them it was a pretentious falsehood. (74)

In making an "objective justification of Hugo's attitude", the written dialogue betrays the spirit of Jake's exploratory spoken exchanges with Hugo. Hugo's approach to conversation is close to what Sennett celebrates as the "subjunctive mood", which is "most at home in the dialogical domain, that world of talk which makes an open social space, where discussion can take an unforeseen direction" (23). Murdoch portrays the decay of dialogue in the transition from spoken exchange to printed book-as if the liberal novel's staging of civilised dialogue and open-ended democratic deliberation disguises a hardened didactic purpose.

This set of problems might be seen as quite far from the political as such, but it becomes a crucial part of the context for Lefty's entry into the text, and for the broadly Marxist position that he articulates, monologically. In obvious opposition to Hugo, Lefty does have a single Weltanschauung. There are two primary contexts in which this is conveyed to the reader. The first is itself an extended dialogue between Jake and Lefty, conducted under the influence of a great deal of brandy, while the second is a more public speech by Lefty at a crowded event. I will take these in turn.

The conversation between Lefty and Jake resonates with Jake's dialogues with Hugo, and with his subsequent distillation (and, by his own account, travestying) of those conversations in The Silencer. Lefty's approach to conversation represents a 
contrasting form of character-character dialogue, closely connected to his political commitments. Jake notes: "I was beginning to be annoyed by this question and answer method. He asked each question as if there was one precise answer to it. It was like the catechism" (122). The role of the question in conversation and in character-character dialogue could be thought to exist on a kind of spectrum, with the entirely ritualised, liturgical operations of the catechism at one end, and Hugo's open-ended probing at the other. The purpose of Lefty's questioning is not to explore a problem in an open-ended way, but to compel agreement.

These tendencies are further explored later when we see Lefty giving a speech to a crowd. While Wells's Masterman is too weak and consumptive to climb onto a soapbox, acts of public oratory are one of the ways in which we tend to encounter left-wing arguments in novels. Lefty's speech is framed by a bravura passage of description. Jake at first does not recognise the speaker, but he recognises the situation, an ancient and powerfully resonant form of crowd spectacle. Jake approaches the scene believing that he is in ancient Rome, listening to "Catiline inflaming the Roman plebs". Then:

The passionate voice continued, pouring out an unending flood of exalted protest and appeal. Some of the words which it was uttering began now to find their way into my ears. It was saying: "And that, comrades, is the way to get rid of the capitalist system. I don't say it's the only way, but I do say it's the best way." I stopped. For all I knew Marxism might rapidly be transforming the study of ancient history; all the same, this sounded rather odd. Then in a flash I realised that the speaker was not Catiline but Lefty. (178) 
When dealing with a first-person narrator reporting political speech indirectly, arguments may be framed in a very particular way, partially reported, or presented as some mishmash of the arguments themselves with the narrator's particular preconceptions and obsessions. Here, the structure and atmosphere of the situation leads Jake to believe (comically) that he has in ancient Rome, but the pivot to directly reported speech brings him back to the present via the recognisable rhetoric of 1950s Marxism.

The first person narrator might be thought to be intrinsically subjective in its presentation of events—or perhaps it would be more accurate to say, the subjectivity of the first person narrator is dramatised as part of the narrative effect. Here Murdoch deploys a detached and analytical register as Jake stands back from the speech itself and explains it to the reader, noting its effect on the crowd somewhat from the outside:

Lefty seemed good for another hour. He was really a remarkable speaker. He spoke simply but without faltering. His discourse was copious and yet well ordered too. Not without flowers, it was not without force either. Although afterwards all I could remember of what he said were a few striking phrases, I had the impression at the time that a closely reasoned argument was being presented. He somehow combined the intimate tone of the popular preacher with the dramatic and inflammatory style of the demagogue. Winged by sincerity and passion, his speech fell like an arrow from above, clean and piercing. The thousand men were under his spell. [...] Opposite and behind the speaker were a number of boards with slogans upon them. (181) 
Both the analogy with ancient Rome and this analysis of the scene itself tend to put the form of political speech on a level with its actual content-the "dramatic and inflammatory style" and the response of the crowd take over from the content of the argument that Lefty makes. Jake only remembers a few striking phrases, perhaps similar to the "slogans" behind Lefty that condense his meaning into readily digestible nuggets. Murdoch's presentation of this episode self-reflexively exploits the simplifying power of political monologue, situating left-wing arguments as an agonistic counterpart to the novel's more dialogistic passages.

The extent to which Lefty's arguments are ones that Murdoch intended promote is more difficult to determine than in the case of Masterman in Kipps, where one can find examples of Wells repeating Masterman's arguments in his political and journalistic writing around the same time. Murdoch had been a member of the Communist Party of Great Britain while a student at Oxford (Spear 4), but it would be difficult to corroborate any claim that Lefty represents her political views in the manner of a "spokesman", even if he does act as a kind of chorus character in the novel. Rather, in Under the Net, Murdoch seeks to test Marxist arguments against certain philosophical ideas, with which she was also sympathetic. Hugo's dialogical conversational style is starkly contrasted with Lefty's more monological one, and Hugo's anti-foundational philosophical ideas tend to pull the rug out from under any all-embracing theory such as Lefty's Marxism. In this context it is perhaps surprising that towards the end of the novel Hugo is drawn under Lefty's spell, and donates substantial money to Lefty's party. "I didn't know you had any political views", Jake says. Hugo replies, “I haven't exactly got political views [...] but I think Lefty's ideas are decent" (283). Moreover, the divergence between Lefty's urgent call for political 
engagement and Jake's bohemian tendencies achieves a partial resolution at the end when Lefty writes Jake a conciliatory letter:

He suggested that [...] I should come and call on him: and if I felt I could do any political work he would be glad, but that I should call anyway; after all, life wasn't entirely a matter of politics, was it? I got a good impression from this letter; and although I doubted whether Lefty really entertained the final sentiment I felt that here I had to do with a man (313).

The novel ends, then, with various kinds of accommodation between seemingly incompatible intellectual and political positions-Hugo's Wittgensteinian antifoundationalism, Lefty's Marxism, Jake's bohemian dilettantism. The challenge of Lefty's Marxist arguments is somewhat diffused by personal affection, as Jake comes to respect him as a "man".

The question I am left with is to what extent Murdoch's novel reabsorbs Lefty's agonistic speech into the realm of deliberative liberal dialogue. Certainly, Under the Net exemplifies the ways in which the novel can be a plural space where incompatible arguments do not escalate into antagonism, and which accommodates political disagreement, action, and commitment. Yet as Murdoch's novel seemed to suggest in relation to Jake's publication of The Silencer, liberal dialogue can itself become a didactic tool. Under the Net seems to ask whether the novel form's seemingly intrinsic dialogism has the potential to commit the novelist in advance to the values of liberalism. To what extent are the dissident left-wing arguments that are voiced in novels integrated in advance into a form of civilized liberal dialogue? Mouffe's theorisation of agonism navigates a version of this problem. She warns of 
the dangers of a too-restrictive "consensus at the centre," as noted above-but it should be emphasised that her account of agonism is also mobilised as an alternative to the sort of violent antagonism that feeds "clash of civilisations" rhetoric (2013 41). She writes: "instead of trying to bring about a consensus that would eliminate the very possibility of antagonism, the crucial task ... is to find ways to deal with conflicts so as to minimize the possibility that they will take an antagonistic form" (23). Mouffe celebrates the "agonistic encounter" as a "confrontation where the aim is neither the annihilation nor the assimilation of the other, and where the tensions between the different approaches contribute to enhancing the pluralism that characterises a multipolar world" (41). Mouffe's call is for a "radicalization, not a rejection, of liberal democratic institutions" (xviii). Murdoch builds into Under the Net an inflexibly monologistic and didactic form of political speech, delivered by Lefty who operates as a kind of chorus character. But that speech exists in an agonistic relation to the novel's other discourses rather than in a fight to the death, where annihilation or assimilation are the only possible outcomes.

\section{A Proper Marriage}

In the fiction of Doris Lessing, left-wing political speech is a common feature. Lessing's justifiably celebrated novel The Golden Notebook (1962) is an investigation of the forces that precipitated Lessing's departure from the Communist Party in 1956, alongside many intellectuals of the New Left, and Amanda Anderson draws on the pervasive cynicism of its characters, and its fragmentary form, to show how the novel articulates bleak liberal arguments (128-141). Such a framework 
cannot easily be adapted to A Proper Marriage (1954), published when Lessing was still a prominent member of the Communist Party of Great Britain. A Proper Marriage dramatises the unhappy marriage of Martha Quest (Lessing's fictional alter ego) to Douglas Knowell, in the fictional colony of Zambesia (a fictionalised version of Southern Rhodesia where Lessing herself grew up). The story is set around the outbreak of the Second World War, which sees Douglas sent away to train for the army, though he misses out on active service through ill health. Martha's disillusionment with her marriage is tied up with her move towards Communism, and the political arguments articulated by the novel's left-wing and Communist characters are in counterpoint, not necessarily with an opposing set of political arguments, but with the pervasive ideology of marriage itself. “You can't be a Red if you're married to a civil servant" (33), Stella tells Martha in Chapter One, establishing the central choice that Martha must make, and which is decided in favour of political commitment at the end of the novel. On hearing of Martha's marriage, Solly Cohen, one of her left-wing friends, writes her a pitying letter, casting her as a "victim of the system":

I'm not surprised, you are a born marrier ... I hear high civil service prospects, pension, and no doubt a big house in the suburbs. ... Well, well, you'll have to be a good girl now, no naughty ideas about the colour bar — no ideas of any kind, for that matter. If there's one thing you can't afford, dear Matty, in the station of life to which you've chosen to marry, god help you, it is ideas. (48)

The opposition between "ideas" (or just as often "politics") and "marriage" is the intellectual core of $A$ Proper Marriage. It is an asymmetrical opposition, in that it pits 
a set of political and intellectual arguments against—not an alternative set of arguments, but a way of life, an ideology (in the sense of a false consciousness).

In A Proper Marriage, there are a number of different characters who could be thought to play the role of left-wing chorus character, but the German-Jewish refugee Anton Hesse (although he appears only late in the novel) has a galvanising effect on the assortment of colonial leftists he finds there. Anton goes on to become the leading voice in the group (as well as, somewhat ironically, Martha's second husband) in the next instalment of the Children of Violence sequence, A Ripple from the Storm (1958). Anton's entrance into the novel presents a different case from the corresponding chorus characters in Kipps or Under the Net. While Lessing's narration is often focalised through Martha, there are also moments where the narration tilts in a more omniscient direction. Anton's political formation and motivations are set out by the narrator in a way that goes far beyond Martha's knowledge of them:

he was conscious that his analysis of the situation had a factor in it that he ought to be ashamed of. He knew he didn't want to take part in politics in this country. [...] He loathed the empty, ill-educated, easygoing colonials; he despised the life of sundowners and good times. He hated everything down to the food and drink. [...] He spent his time reading the Marxist classics and studying Russian. He was a man in cold storage for the future. (385)

The careful framing of Anton's arguments with this account of his conflicted motivations, and-in the final sentence quoted-a semi-ironic ethical judgement on him, complicates the idea that his arguments are presented as unmediated content. 
By foregrounding character and rhetorical style as much as argument, and putting these into dialogue, A Proper Marriage captures the novel's capacity to investigate how political arguments are socially and psychologically situated.

Ngai argues that novels of ideas are dominated by "the 'real time' of scene", as character-character dialogue takes over from "narration" (in the sense Lukács famously elaborates in "Narrate or Describe"). For Ngai, this takes the novel away from its temporal "métier": the uniquely novelistic capacity to summarise long stretches of time in a sentence or (conversely) to allow a moment to dilate over several pages (118). The drama of a scene dominated by character-character dialogue, arguments and ideas is perhaps not as alien to the novel as Ngai suggests. Moreover, political novels of ideas (Doris Lessing's in particular) frequently excel at narration, in the Lukácsian sense. In A Proper Marriage, after Martha has read a paper on education in the Soviet Union to the group, she observes the way in which Anton leads and controls the discussion: "she was already familiar with this atmosphere when everyone in a room was in willing submission to Anton, who was able to answer any problem with two paragraphs at least (one always felt he was reading from an invisible book) of clear grammatical prose" (401). This is undoubtedly a dramatic scene of argument, but the synchronic depiction of scene is interlaced with diachronic authorial touches ("one always felt", "she was already familiar") which emphasise the typicality of the manner in which Anton presents his arguments. In this particular meeting Anton's views on education in the Soviet Union are not reported in direct speech at all. We know that he is an orthodox Leninist with years of experience in the KPD. Informed readers can perhaps supply the "paragraphs ... from an invisible book" themselves. Lessing wants us to focus on the effect of these arguments in the (fictional) room. 
The ideas and arguments that go to make up the intellectual formation of Marxism-Leninism are as much concerned with political strategy as with the elements of Marxist sociology and materialist philosophy. A Proper Marriage (like many other Communist novels) foregrounds debates about political strategy rather than philosophy, and the discussions towards the end of the novel, after Anton enters the narrative, turn on the question of whether it is a good idea to form a Communist group in the colonial backwater of Zambesia, with a likely membership of around twenty. It is worth quoting in full the way Anton's argument is presented:

Anton Hesse glanced around, saw that everyone was looking towards him, turned to Joss, and said, 'You know what the situation is. I propose to analyse the position as I see it. Afterwards the others can argue against me.'

He spoke for about half an hour. For most of the people in the room, it was the first time they had heard a Marxist explaining the world. It was right over their heads. He was in fact speaking to Andrew McGrew, Boris Kreuger, Joss Cohen, Sergeant Bolton. For the others, such was their innocence that they were realizing that a vague enthusiasm for the Soviet Union was not Marxism - they had imagined they were already initiates when in fact they knew nothing. They listened, watching the four intent men, with an awed respect, while Anton Hesse analysed the world situation, considered the British Empire, dealt with the colony in which he now found himself; its class forces were thus, its potentialities so, and the stage of development it had reached was... The conclusion was ten minutes of facts, figures, quotations from white and blue papers, which were all neatly ranged in his head, for he had no notes. 
His final sentence was, 'While everyone in this room would agree that a Communist Party is necessary and desirable, I submit that it would be inadvisable to start one with the existing cadres.' (403-4, Lessing's ellipsis)

The narrator is reticent to include some of the details of the argument, while conveying its overall shape. Even when some of Anton's exact words seem to leak into the narrator's indirect report ("its class forces were thus, its potentialities so, and the stage of development it had reached was..."), the narrator substitutes "thus", "so" and an ellipsis for the actual evidence which builds towards Anton's summative statement of his position, given in direct speech. Lessing's presentation again emphasises the effects of Anton's argument on the listeners over whose heads it went. After describing their 'innocence', the narrator's selective summary seems to reflect the listening experience of the cadres present. Their attention dwells on the recognisably Marxist rhetorical features of his discourse ("analyse the situation", "class features", "potentialities", "stage of development"): what they hear is a collection of Marxist-sounding arguments, followed by a bald and rather unwelcome conclusion: that they are not ready to be Communists. ${ }^{\text {iv }}$

Lessing's depiction of the debate that follows Anton's speech investigates the relationship between agonistic debate and collective solidarity. Of the twenty present at this meeting, the five or six people who are most invested in the idea of creating a Communist group are those (including Martha) who are normally resident in the colony: the rest of the group have been brought there by the temporary circumstances of war (many as RAF pilots). Before any of them speaks, this group seem to feel in unison: 
These five looked towards Joss. They felt that he, one of them, brought up in the colony, would understand them, whereas these cold-minded logicians would not, for if every word Anton Hesse had said was true-and they were too ill-informed to know whether it was or not-he completely ignored the passion for service which filled them all. (404)

These locals are largely observers in the debate that follows, which pits the cold logic of Anton against calls for the immediate establishment of a Communist group, framed as passionate cries for justice. They find this disagreement painful to watch. Whereas Anton had begun his oration with an invitation to disagreement ("Afterwards the others can argue against me"), the "passion for service" felt by this group becomes a call for consensus: "They longed only to throw themselves 'for once and for all' into complete self-abnegation ... they wanted a complete unanimity, a fused purpose" (406-7). Mouffe sees such a desire to transcend antagonism as a central failing of communism itself. Answering those left intellectuals like Alain Badiou and Slavoj Žižek who have argued for a revival of communist ideas, Mouffe writes:

It is the very notion of 'communism' that needs to be problematized because it strongly connotes the anti-political vision of a society where antagonisms have been eradicated and where law, the state and other regulatory institutions have become irrelevant. The main shortcoming of the Marxist approach lies in its inability to acknowledge the crucial role of what I call 'the political'. (83) 
Martha and the other locals yearn for their group to be a microcosm of a society in which all antagonisms have been transcended. In the end the group is created, but from its inception it is anything but unanimous. Alliances and subgroups are already starting to form. Anton understands and expects politics to work in this agonistic way, even if there is an underlying dogmatism in his argumentative style, hinted at by the repeated suggestion that his discourse is pre-scripted ("white and blue papers [...] all neatly ranged in his head", "reading from an invisible book"). Anton might be understood, a bit like Murdoch's Lefty, to suffer from the "fetish of assertion" which, for Sennett, makes a truly dialogical conversation impossible. He accepts that politics is an intrinsically agonistic realm. By contrast, Martha and the other locals are painted as naive idealists who understand political commitment as adherence to a creed that absolves them of the need to debate and disagree.

Under these pressures, the novel's central opposition between marriage and politics becomes freshly complex by the end. Martha needs to hang on to the terms of this rigid opposition, in order to initiate the final break from her clingy husband and the banal colonial world of cocktail parties he represents. Here, she tries to explain (to local busybody Mrs Talbot) that she is not leaving for another man:

The words 'I am leaving him to live differently' came to her tongue; she did not say them, because they sounded absurd .... Then she saw Anton Hesse in her mind's eye and brought out aggressively, 'I'm going to live differently'. (p.416)

Martha's aggressive conversational gambit draws inspiration from Anton, in that rather than using indirection to seek common ground with her interlocutor, she seeks 
to refine her own point of view and state it with clarity and force. The reader has already learned that Martha's understanding of political commitment, as a matter of submitting to a fixed consensus, is far from the reality of the group. Martha does not fully understand it yet, but in escaping from marriage and into politics she is moving into an inherently agonistic sphere.

These concerns-about the personal vs. the political, the individual vs. the collective, the possibilities and the limitations of political debate-are abiding ones throughout the Children of Violence sequence. The final novel in the sequence, Four Gated City (1969), was written long after Lessing's public departure from the CPGB in 1956, and follows her fictionalised alter ego Martha Quest into this postCommunist period too. Like Lessing, Martha continues to be politically engaged after leaving the Party. But this final novel in the sequence charts a reverse process whereby the desire to form meaningful political collectivities that can speak in chorus is increasingly countered by strains of individualism and pluralism. This is exemplified in the chapter that describes Martha and her comrades attending the Aldermaston Marches against nuclear weapons.

The discussions that went on up and down the columns were infinitely in advance of the slogans on the banners and placards; which might account for the numbers of people who chanted slogans like 'Ban the Bomb' and so on as if they found the syllables absurd. Of course it is not possible to have a political slogan that is anything but simple and therefore absurd. But there probably has never been a political demonstration where the content of people's talk was more divergent from the banners they walked under. In 
imagination they were exploring worlds of extraordinary possibilities, change, discovery, revolution; meanwhile they chanted Ban the Bomb and Down With... and Hands Off... (430, Lessing's ellipses)

Lessing here counterposes a view of political commitment as the monological chanting of slogans on which there is a consensus, with one where wide-ranging and open-ended discussions are integral to what politics means. Few writers make better use of ellipses than Lessing (even if she uses them sparingly), and here (as in the summary of Anton's speech above) they help to emphasise that the form of these collective utterances takes precedence over the actual things the crowd shouts for or against. The slogans that represent collective, monologic speech seem a blunt instrument compared to the unfolding democratic negotiation that is going on under the banners, yet perhaps there is a necessary relationship between the two: intransigent and monological left-wing dissidence as a necessary component of an agonistic democratic politics.

I have tried to show here that left-wing arguments articulated in political novels are both rooted in the real world and skilfully situated in the diegetic worlds of fiction, where they confront counter-arguments but also and perhaps more importantly habits, ways of life, ideologies, institutions and mores that enable or constrain the uptake and effects of given political arguments. The political novel is a kind of laboratory where abstract political ideas meet (in fiction, and under controlled conditions) a bodily and creatural reality. 


\section{Works Cited}

Adorno, Theodor W.. Aesthetic Theory. Trans. by Robert Hullot-Kentor. Continuum, 2002.

Anderson, Amanda. Bleak Liberalism. Chicago UP, 2016.

Anderson, Amanda. Psyche and Ethos: Moral Life after Psychology. Oxford UP, 2018.

Armstrong, Isobel. Novel Politics: Democratic Imaginations in Nineteenth-Century Fiction. Oxford UP, 2016.

Best, Stephen and Sharon Marcus. "Surface Reading: An Introduction." Representations, Vol. 108, No.1 (Fall 2009) pp.1-21.

Cheyette, Bryan. Constructions of 'The Jew' in English Literature and Society. Cambridge, 1993.

Conradi, Peter J. Iris Murdoch: The Saint and the Artist. Macmillan, 1989.

Felski, Rita. "Identifying with Characters." Character: Three Inquiries in Literary Studies by Amanda Anderson, Rita Fells and Toril Moi. Chicago UP, 2019, pp.77126. 
Jackson, Jeanne-Marie. "Plurality in Question: Zimbabwe and the Agonistic African Novel." Novel: A Forum on Fiction, vol.51, no.2, 2018, p.339-361.

Kohlmann, Benjamin. Committed Styles: Modernism, Politics, and Left-Wing Literature in the 1930s. Oxford UP, 2014.

Kohlmann, Benjamin. Speculative States: British Literature, Institutionality, and Reform. Oxford UP, forthcoming 2021.

Kohlmann, Benjamin and Matthew Taunton. "Introduction: The Long 1930s." A History of 1930s British Literature, edited by Kohlmann and Taunton, Cambridge UP, 2019, pp.1-14.

Lessing, Doris. A Proper Marriage. Paladin, 1990.

Lessing, Doris. The Four-Gated City. Granada, 1972.

Lukács, Georg. "Narrate or Describe?" Translated by Arthur Kahn. In Writer and Critic and Other Essays. Merlin Press, 1970. pp.110-48.

McCarthy, Mary. Ideas and the Novel. Weidenfeld and Nicholson, 1981.

Moi, Toril. "Rethinking Character" in Character: Three Inquiries in Literary Studies by Amanda Anderson, Toril Moi and Rita Felski, Chicago UP, 2019, pp.27-75. 
Mouffe, Chantal. Agonistics: Thinking the World Politically. Verso, 2013.

Mouffe, Chantal. For a Left Populism. Verso, 2019.

Moufte, Chantal. On the Political. Routledge, 2005.

Nietzsche, Friedrich. The Birth of Tragedy, trans. by Shaun Whiteside. Penguin Books, 1993.

Partington, John. "The Death of the Static: H.G. Wells and the Kinetic Utopia." Utopian Studies vol.11, no.2., 2000, pp.96-111.

Penteado, Bruno. "Against Surface Reading: Just Literality and the Politics of Reading." Mosaic: an interdisciplinary critical journal, vol. 52 no. 3, 2019, pp.85-100.

Sennett, Richard. Together: The Rituals, Pleasures and Politics of Cooperation. Penguin Books, 2013.

Spender, Stephen. World Within World: The Autobiography of Stephen Spender. Hamish Hamilton, 1951.

Spear, Hilda D. Iris Murdoch. Macmillan, 1995.

Well, H.G. Kipps: The Story of a Simple Soul. Heron Books, 1968. 
Wilson, Harris. "The Death of Masterman: A Repressed Episode in H. G. Wells's

Kipps.” PMLA, Vol. 86, No. 1 (Jan., 1971), pp. 63-69.

\footnotetext{
i Modern dramatic deployments of choruses, such as those by Brecht, Auden and Isherwood, echo discussions around the political novel, raising similar questions about commitment, collective voicing, and debate

ii Benjamin Kohlmann's forthcoming Speculative States (2021) situates Masterman's arguments in relation to Wells's political ideas.

iii For a discussion of Wells and antisemitism, see Cheyette 94-149. John Partington points out that Wells condemned racism. For example in his 1907 article, "Race Prejudice", where Wells writes: "if any one wants a creditable dragon to write against, talk against, study against, subscribe against, work against, I am convinced they can find no better one-that is to say, no worse one-than Race Prejudice" (qtd in Partington 100-101).

iv For more on Lessing's engagement with Communist language, see Matthew Taunton, "Communism by the Letter: Doris Lessing and the Politics of Writing" in ELH 88:1 (forthcoming).
} 